\title{
New stratigraphic interpretation of the Soultz-sous-Forêts 30-year-old geothermal wells calibrated on the recent one from Rittershoffen (Upper Rhine Graben, France)
}

\author{
C. Aichholzer ${ }^{1 *}$, Ph. Duringer ${ }^{1}$, S. Orciani ${ }^{2}$ and A. Genter ${ }^{3}$
}

\section{${ }^{*}$ Correspondence:}

caichholzer@unistra.fr

${ }^{1}$ Institut de Physique du Globe de Strasbourg (IPGS), UMR 7516, CNRS-Université de Strasbourg EOST, 1 rue Blessig, 67084 Strasbourg Cedex, France

Full list of author information is available at the end of the article

\begin{abstract}
The Soultz-sous-Forêts site (Alsace, France) is the first pilot geothermal project in the world that furnished the proof of concept of enhanced geothermal systems by producing energy from a deep-seated granite. The Alsace region, with its hundreds of previous drillings and seismic history related to both oil and potash exploitation, has been shown to have high subterranean temperatures. In the Soultz-sous-Forêts geothermal project, most attention has focused on the basement and the sedimentary cover/basement interface. Thus, the sedimentary portion of the well (approximately $1.4 \mathrm{~km}$ thick) has never been fully investigated. The only available data on the Soultzsous-Forêts sedimentary cover are from an old masterlog (GPK-1) with interpretations of the tops and bases of the main geological formations, and from some other less well-documented well logs (EPS-1 and GPK-2). The main challenge of this work is therefore to re-interpret the old well data to provide precise and detailed chronolithostratigraphic logs for GPK-1 and GPK-2, especially in their sedimentary portions. These new investigations of the GPK wells have been possible due to the new data collected in the recent geothermal wells at Rittershoffen (GRT-1 and GRT-2, located $6.5 \mathrm{~km}$ from Soultz-sous-Forêts), which are characterized by a quite complete stratigraphic succession. Both sites have been explored by deep drilling operations aiming to exploit the heat extracted from a deep granitic basement (Palaeozoic) covered by a stack of 1.4- and 2.2-km-thick sedimentary rocks (Mesozoic to Cenozoic) at Soultz-sous-Forêts and Rittershoffen, respectively. Thus, the Rittershoffen chrono-lithostratigraphic logs have been used as a baseline to interpret the sedimentary succession in GPK-1 and GPK-2. In conclusion, all the well logs are compared for stratigraphic comparisons. With approximately $1400 \mathrm{~m}$ of sedimentary cover at Soultz-sous-Forêts instead of $2200 \mathrm{~m}$ at Rittershoffen, the correlation between the two sites showed many differences exist in the sedimentary columns: layers missing due to erosion, lateral thickness variations in formations, and-above all — the occurrence of at least four major fracture zones affecting the units. In addition, a structural analysis was made to more precisely define the limits of the geological formations observed and to present more arguments for the presence of fracture zones or faults.
\end{abstract}

Keywords: Geothermal energy, Well, Stratigraphy, Rift, Gamma ray, Rittershoffen, Soultz-sous-Forêts, Alsace 


\section{Background}

\section{Introduction}

Due to the "West European Palaeogene Rift System", the geothermal gradient is abnormally high in Northern Alsace (with temperatures of $\sim 50{ }^{\circ} \mathrm{C}$ noted at depths of $400 \mathrm{~m}$ ) (Fig. 1). In this region, there are thousands of oil wells and seismic profiles, which have highlighted the high temperatures in both the sediments and the basement (Haas and Hoffmann 1929). These high subterranean temperatures have led to different geothermal

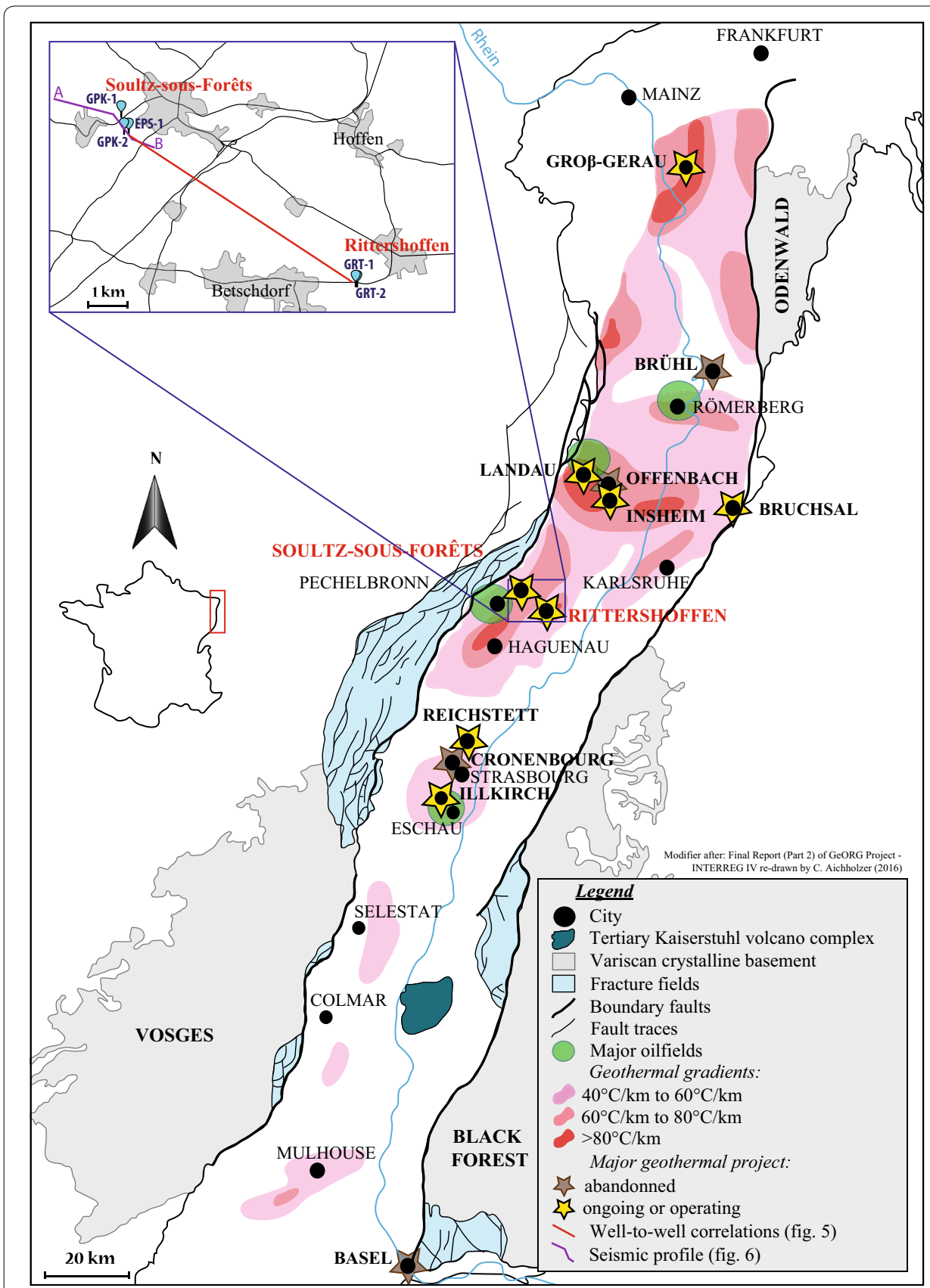

Fig. 1 Map of the extrapolate temperatures of the Upper Rhine Graben region at $1 \mathrm{~km}$ depth. Main oilfields and major geothermal projects projected on the map. Re-drawn from GeORG (2004), version modified 
projects in the Alsace region. The Upper Rhine Graben (URG) is therefore one of the most studied regions in Europe, mainly for petroleum and potash exploitation, and recently for geothermal applications, such as the projects on the French side at the Soultz-sous-Forêts geothermal pilot site and the Rittershoffen industrial geothermal site. To maximize the geothermal exploitation, the main development goal involves reaching the highest temperature and flowrate conditions at the shallowest depth. In Northern Alsace, enhanced geothermal systems (EGS) technology was developed and consists of hydraulic and/or chemical stimulation to increase the low natural hydraulic performance of a geothermal reservoir (Gérard et al. 2006a; Schulte et al. 2010). Thus, the EGS concept involves creating connections between the hydraulic boreholes by the reactivation of pre-existing fractures in the granite (Evans et al. 2005) and then capturing brines present within the naturally fractured reservoirs.

Between 2012 and 2014, at Rittershoffen, two new geothermal boreholes-GRT-1 and GRT-2-were successfully drilled into the granitic basement to final depths of 2562 and $2707 \mathrm{~m}$ vertical depth, respectively (Baujard et al. 2015). This doublet was the subject of particular attention in the acquisition of a very precise stratigraphic profile (Aichholzer et al. 2015). GRT-1 and GRT-2 have been used as a reference well for the chrono-lithostratigraphic analysis that aims to reinterpret the Soultz-sous-Forêts wells GPK-1 and GPK-2, which were drilled in 1987 and 1995, respectively. At Soultz-sousForêts, the five deep boreholes closely spaced at approximately $500 \mathrm{~m}$ (EPS-1, GPK-1, GPK-2, GPK-3 and GPK-4), provide abundant geological and geophysical data for the Soultz-sous-Forêts site. The EPS-1 borehole is an old oil well deepened and fully cored from 930 to $2227 \mathrm{~m}$ (mainly in the lower Triassic) to characterize the granite reservoir, and used as an observation well for geothermal exploration (Dezayes et al. 2005). The four other wells (GPK-1-4) were drilled for power production (Gérard et al. 2006b). To date, no precise geological and stratigraphic logs with the sedimentary formations have been developed in Soultz-sous-Forêts because the primary objective was to characterize the deep fractured Palaeozoic crystalline basement (Genter et al. 2015). Only the deep Permo-Triassic clastic sandstone overlying the basement has been examined using a continuous core analysis because the cover/basement interface is part of the heat reservoir. During drilling operations, from both technical and geological perspectives, it is very important to know the nature of the sedimentary cover and the precise position of the tops and bases of the main stratigraphic formations. The sedimentary cover/ basement interface is the overarching goal for geothermal exploration because the heat circulates through it via a vertical fracture network permitting hydrothermal convective cells (Pribnow and Schellschmidt 2000).

To understand the regional geology of the site, it is necessary to know all the geological formations from the top to the base of the wells, especially if other projects are planned. In this case, stratigraphic information is very useful for well design (diameter, technical section, and trajectory). Before the GRT-1 litho-stratigraphic results (Aichholzer et al. 2015), no precise stratigraphic log except the geological maps after Ménillet et al. 2015 existed in the area of the complete sedimentary cover. These geological analyses seriously improve the knowledge of the sedimentary part of the deep geothermal wells and therefore improve future geothermal project development. After reviewing the geological context of Northern Alsace, a detailed stratigraphic analysis, which has been 
calibrated based on recently acquired knowledge at Rittershoffen (via cuttings information and radioactivity logs, such as gamma ray (GR) logs), is proposed for the 29-yearold geothermal wells of Soultz-sous-Forêts. In addition to the stratigraphic contribution, a structural analysis of the main fracture zones intersecting the sedimentary part of the Soultz-sous-Forêts wells is proposed. This structural analysis is based on different scales: large scale with the seismic profile (Cautru 1988 redrawn by Koelbel et al. 2011), 2D visualization with the well-to-well correlations and 1D with borehole data (mud logging, well logs) (Vidal et al. 2015). The goal of this analysis is to interpret the thickness variations of the stratigraphic units to identify the zones affected by faults with the help of other data (seismic profile and mud logging).

\section{Geological setting}

The URG is part of a series of rifts in the "West European Palaeogene Rift System", which extends over $1000 \mathrm{~km}$ from Spain to the north of Holland into the North Sea (Illies 1967; Bergerat 1985; Brun and Wenzel 1991; Schumacher 2002; Ziegler and Dèzes 2005; Rotstein et al. 2005; Edel et al. 2007; Bauer et al. 2015). The URG is located in north-eastern France (Fig. 1). The graben has an average strike of NNE-SSW. It is an asymmetrical graben with thicker deposits in the north than in the south and is composed of many sub-basins that are all different from each other. Indeed, these sub-basins reflect the geological history of the URG, and all of them have a particular architecture and history, especially during the Tertiary (Sittler 1969a, b; Rousse 2006; Duringer 2014). The URG, with its French part in Alsace, extends from the Jura Mountains (south) to the Rhenish Massif (north). The rift basin was explored for oil and potash (the latter especially in the southern part of the graben) (Haas and Hoffmann 1929; Clapp 1932; Schnaebele et al. 1948; Blumenroeder 1962; Blanc-Valleron 1990; Wannesson 1998) and is now mainly exploited for geothermal energy (Munck et al. 1979; Genter et al. 2003; Gérard and Kappelmeyer 1987; Gérard et al. 2006a; Genter et al. 2015). In fact, the Alsace region has become a remarkable site for deep geothermal projects because of its high thermal gradient (up to $100{ }^{\circ} \mathrm{C} / \mathrm{km}$ in the uppermost part of the sedimentary cover) (Fig. 1) and by the presence of natural brines (on the order of $100 \mathrm{~g} / \mathrm{L}$ ) transporting heat to the surface of the Earth (Housse 1984; Schellschmidt and Schultz 1991; Carlier et al. 1992; Vernoux et al. 1995; Sanjuan et al. 2010). As granite is a naturally radioactive rock, heat production is enhanced by the decay of radionuclides, and the abundant fluids circulating through the fractured granitic basement transport that heat. All of these reasons explain the 29-year-old Soultz-sous-Forêts geothermal pilot project (1987) and the development of many recent geothermal projects in Alsace (Genter et al. 2015).

The deep Palaeozoic granitic basement lies at a depth of $2200 \mathrm{~m}$ at Rittershoffen compared $1400 \mathrm{~m}$ at Soultz-sous-Forêts, which are located approximately $6.5 \mathrm{~km}$ from each other. These two geothermal sites have a similar litho-chronostratigraphic column including, from the base upwards, a granitic basement covered by a reduced Permian clastic formation, the entire Triassic sequence (Buntsandstein, Muschelkalk and Keuper), reduced Jurassic units (Lias and lowermost Dogger; Malm has been eroded; and Cretaceous sediments were deposited because the region experienced major uplift during the early rifting phase starting in the late Jurassic) and portions of Eocene, lower Oligocene and Pliocene sediments (Duringer 1995). A major erosional unconformity 
separates the Mesozoic from the Tertiary units, which are composed exclusively of Eocene (Palaeocene deposits have not been identified), lower Oligocene and a portion of Pliocene sedimentary rocks (Sittler 1969a, b; Duringer 1988; Schuler 1990; Sissingh 1998, 2003; Berger et al. 2005; Ménillet et al. 2015). These Tertiary layers are related to the opening of the graben from the middle Eocene. In this geographical area (Soultzsous-Forêts and Rittershoffen), the upper Oligocene and Miocene do not exist because of erosion. The uppermost part of the sedimentary cover is a clayey-loess unit dating from the Pleistocene (Ménillet et al. 2015). The interpreted depositional environmental characteristics in this stratigraphic column (Aichholzer et al. 2015) are as follows: the Pliocene-Quaternary period is characterized by loess deposits during the Quaternary and fluvial, marshy and lake deposits during the Pliocene. The Oligocene is characterized by marine deposits in the upper part (Série Grise) and lacustrine to evaporitic deposits in the lower part (Couches de Pechelbronn). The Eocene is fully lacustrine and/or evaporitic according to the position in the rift. Close to the rift border, on the French side (the Vosges), (not represented on the log), marly facies from the basin rapidly become conglomeratic (fan-delta from rift borders) (Duringer 1988, 1995; Duringer and Gall 1994 ). The Jurassic is fully marine. From the top to the base of the sequence, the Triassic is characterized by lagoonal environments (Keuper), marine-to-lagoonal environments (Muschelkalk) and fluvial (lower Buntsandstein) to fluvio-deltaic environments in the upper part of the Buntsandstein (Grès à Voltzia). Some parts of the Buntsandstein (especially the Grès Vosgien supérieur) feature aeolian deposits. The Permian is the oldest sedimentary unit in the graben and overlies the basement. It is characterized by fully continental deposits (from debris cones to fluvial environments).

\section{Methods}

The precise stratigraphic succession of the four GPK wells in Soultz-sous-Forêts has never been investigated to date because the main objectives were to characterize the crystalline basement. This new interpretation is made possible by the results of geological analyses obtained during and after the drilling phase at Rittershoffen. This work will enhance the basement/cover knowledge and determine the precise chrono-lithostratigraphic units crossed by the GPK-1 and GPK-2 wells. At Soultz-sous-Forêts the geothermal plant has four wells, GPK-1, GPK-2, GPK-3 and GPK-4. Because these three latter wells are close to each other, this paper only presents the results of GPK- 1 and GPK-2, which are separated by $493 \mathrm{~m}$. The main goal of this work is to determine the accurate depths of the top and base of each formation and to evaluate their thickness variations between Rittershoffen (GRT-1) and Soultz-sous-Forêts (GPK-1 and, GPK-2). The workflow process involved a critical rereading of the old masterlog with the analysis of the cuttings descriptions and calcimetry log. Next, for calibration, the study of outcrops was associated with the masterlog results and existing cores, especially from the EPS-1 well. Finally, the gamma ray $\log (\mathrm{GR})$ is used to confirm or adjust the position of the tops and bases of the formations because it has the highest resolution. Moreover, for the same stratigraphic boundary, from one well to another, the GR variations (natural radioactivity) are quite similar. GR patterns therefore constitute one of the best geophysical signatures for wells comparisons especially if the descriptions of the series using the cuttings are not sufficient. 


\section{Masterlog and field work}

The masterlog is the report synthesizing the rock succession from the top to the base of the well (e.g., cuttings descriptions, calcimetry log, layer interpretations, rate of penetration (ROP) of the drill bit during the drilling, date and depth, and occurrence of faults). Because it depends on cuttings sampling during drilling, the vertical resolution is no more than approximately $3-5 \mathrm{~m}$ depending on the desired precision. The analysis of cuttings is essential for describing the intersected units. The calcimetry log, especially the calcite/dolomite ratio, can be essential for some formation identification in the Muschelkalk, for example, where the occurrence of dolomite signals the transition between certain units. The rate of penetration of the tool is linked to the lithologic variation (from clay to limestone, for example) but is generally difficult to interpret. It has never been decisive in determining the position of a formation. The occurrence of gypsum/anhydrite is another important tool for determining the position of the units, especially in the Tertiary, in the Keuper and Middle Muschelkalk. Combining the previous results with natural outcrops in Northern Alsace was an essential method for determining of the formation boundaries in the GRT wells, which were used as a reference well for the chronolithostratigraphic vertical succession (Aichholzer et al. 2015).

\section{Sampling}

Sections of core from the EPS-1 well were only available for the Buntsandstein and the lower and middle part of the Muschelkalk, but they increased the accuracy of the results. For example, for the Buntsandstein, the Grès Vosgien is composed from the top to the base of three quite similar sandstone bodies: the Couches de Karlstal, the Couches de Rehberg and the Couches de Trifels. It would have been impossible to determine the tops and bases between these three units without using the cores sections from EPS-1 in combination with a field study. In fact, the GR signature was crucial because each large positive radioactivity peak (Figs. 2, 3) correlates exactly with multi-decimetre argillaceous layers identified in the cores (GPK-1: 1186 m-100 gAPI, 1207 m-111 gAPI and $1214 \mathrm{~m}-120$ gAPI with a average value of 60 gAPI, and GPK-2: $1250.5 \mathrm{~m}-107$ gAPI and 1267 m-90 gAPI with a unit-wide average value of 50 gAPI). Thus, the sedimentological analyses of the cores were fundamental for precisely positioning the stratigraphic tops and bases of the units. In this study, the cuttings were used for all the Soultz-sous-Forêts and Rittershoffen wells except EPS-1 which had continuous cores in the Muschelkalk and Buntsandstein.

\section{Well logs}

Some old wells (e.g., GPK-2) do not have a standard masterlog with a detailed description of the cuttings. These wells only have an internal technical report with the lithostratigraphic interpretation, which cannot be taken as granted. Therefore, if a borehole is well described, like in Rittershoffen, and has a GR log, it is possible to make wellto-well correlations with the other wells due to the radioactive log. A well log (Howell and Frosh 1939) is a continuous record of the variation of a parameter as a function of depth and presents significant advantages, such as providing continuous geological data in addition to cuttings or cores (Desbrandes 1985). Logs are therefore very useful when making multi-well spatial correlations and can provide precise information on 


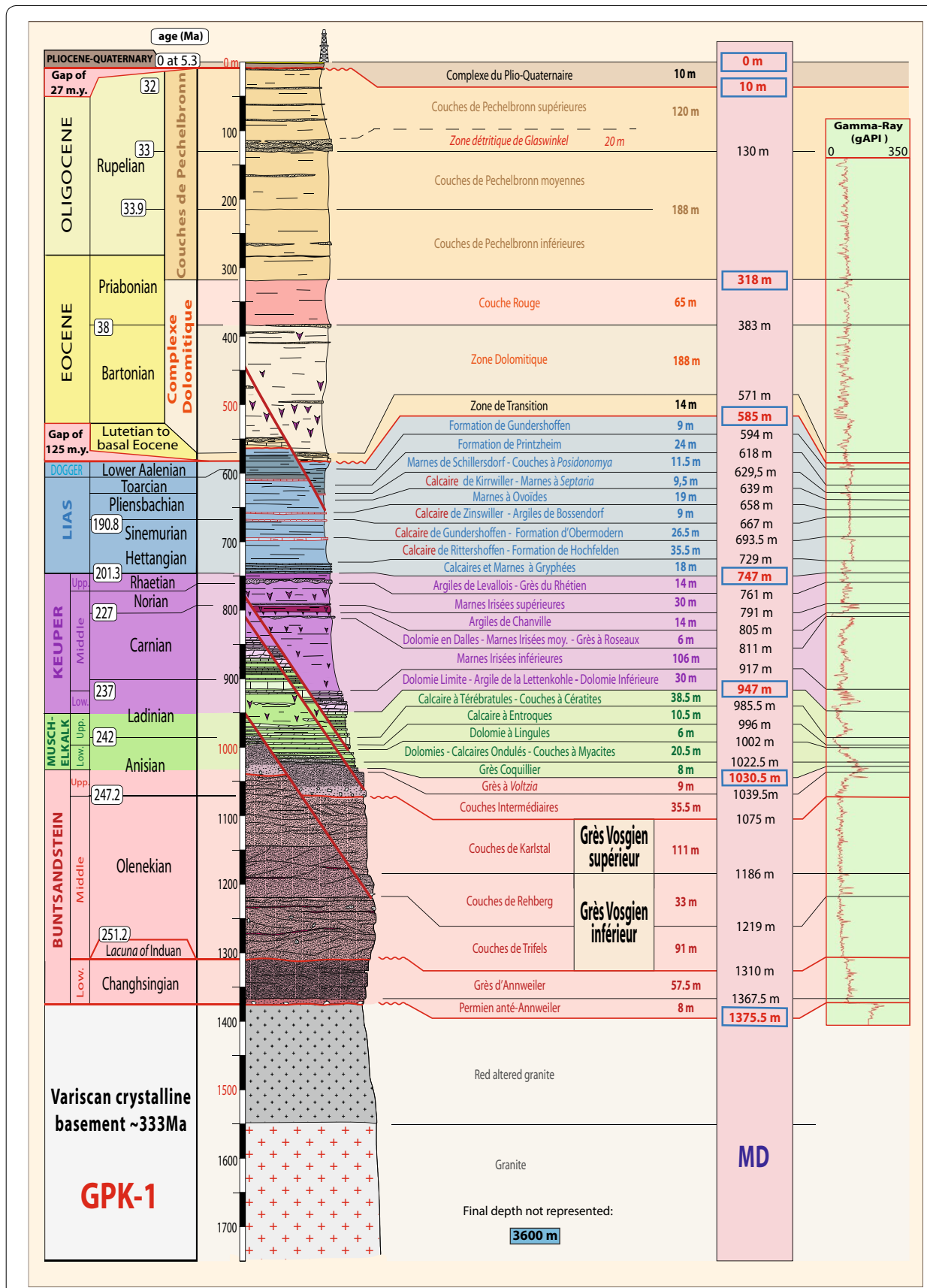

Fig. 2 GPK-1 (Soultz) complete chrono-lithostratigraphic log with the gamma ray log showing all the limits and geological formations encountered

sedimentary deposits and lithologic variations. This paper seeks to define more precisely the tops and bases of the units ( 40 formations in a $2-\mathrm{km}$-thick sequence of rocks) and to show the importance of drilling data. The GR log was obtained by measuring the natural radioactivity produced by the rocks adjacent to the well during the raising of the tool. Emissions of gamma electromagnetic waves come from the decay of naturally radioactive isotopes of elements such as potassium (K), uranium (U) and thorium (Th) (AGR Pioneering Achievements 2013). The measured gamma radiation is either total or 


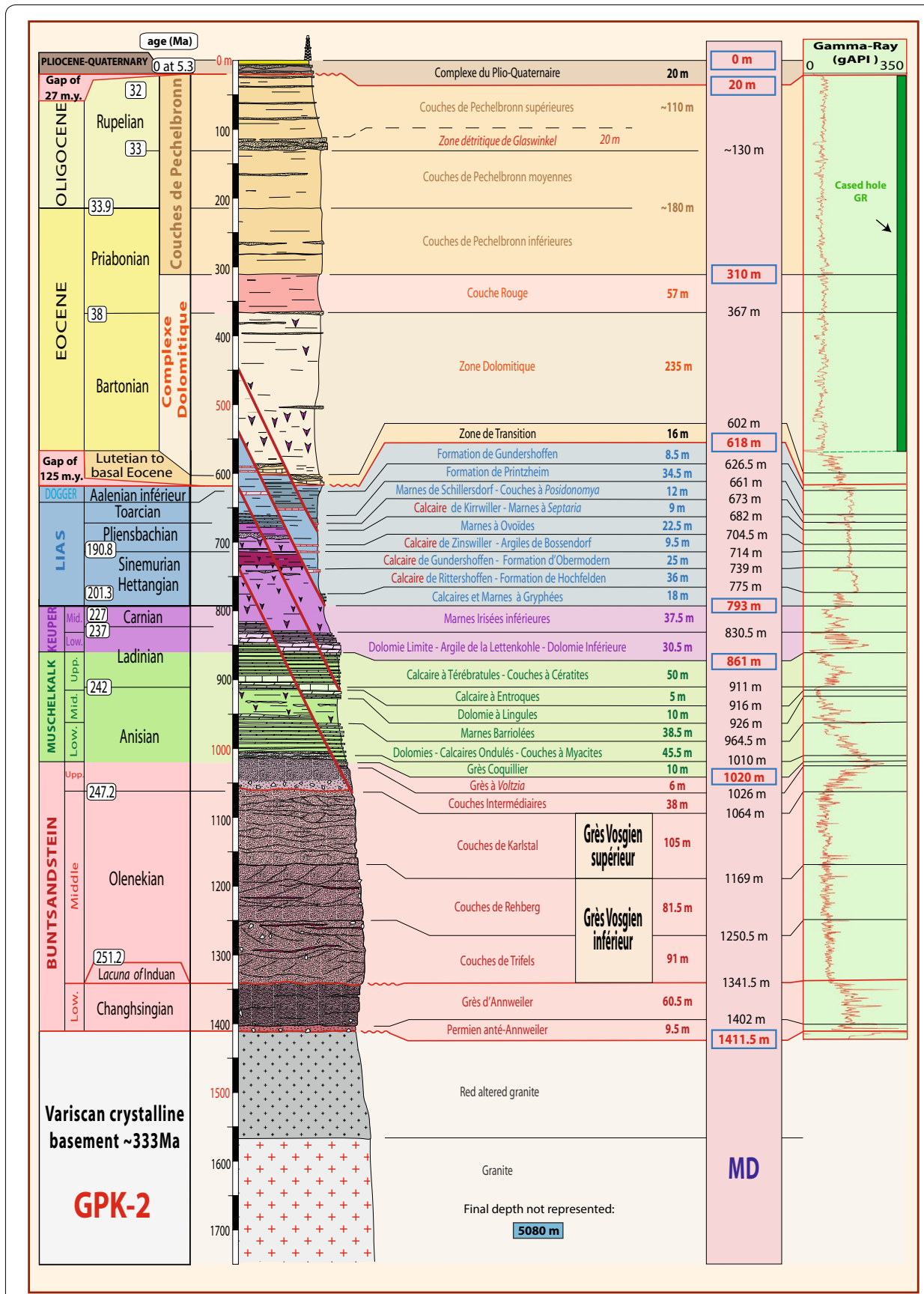

Fig. 3 GPK-2 (Soultz) complete chrono-lithostratigraphic log with the gamma ray log showing all the limits and geological formations encountered

decomposed, known as total GR or spectral GR, respectively. The spectral log isolates the contribution of each of the aforementioned isotopes (Fertl 1979); thus, it is composed of three logs. The vertical resolution of the GR tool, which is used in the wells to acquire the logs, is on the order of $15 \mathrm{~cm}$ (6 in.) (Desbrandes 1985), and the unit of measure is gAPI (giga American Petroleum Institute). A resolution of $15 \mathrm{~cm}$ means that thin units can be identified, which is particularly important for the Lias section, where 
many formation boundaries within this large clayey/marly unit are characterized by only thin deposits. From a practical perspective, clays contain the most radioactive elements, whereas sands, sandstones, limestones and especially for gypsum/anhydrite have very few of these elements. Therefore, sandy-clayey or limestone-clayey sequences are easily recognizable in the GR logs. However, we must be very careful when reading these logs because some minerals, such as sylvite (rich in K) and feldspar (rich in $\mathrm{K}$ and Th), and some types of organic matter (rich in U) can induce positive GR changes (to the right side of the GR log) (Howell and Frosh 1939; Hesselbo 1996; Fiet and Gorin 2000). In addition, the presence of potassium and barite in the drilling mud can lead to increases (to the right) and decreases (to the left), respectively, in the GR signal radiations (Desbrandes 1985). In the Soultz-sous-Forêts geothermal wells, bentonite (Herbrich 1988; Datalog 1995) and salty water were primarily used as drilling fluids. Thus, the GR values have not been influenced by the drilling mud composition. As a final precaution, the intensity of the signal can be greatly reduced when the measurement is made through the casing, but the shape of the signal does not change (Smolen 1995).

\section{Workflow process}

In this paper, the interpreting work requires the analysis of the results of cuttings and cores. After examining these data, the GR logs were used to interpret the unit correlations between the wells of the Soultz-sous-Forêts site. At Rittershoffen each unit is correlated to the GR log. Because a particular signal exists for every layer, the Soultz-sous-Forêts GR logs (from the wells GPK-1 and GPK-2) have been compared to the Rittershoffen logs to define each tops and base of each unit. The analyses of the cuttings brought to the surface during the drilling, the geological knowledge of the region based on relevant outcrops, and the GR log analysis have produced a precise stratigraphic log that contains information on the nature, depth, thickness and age of the geological formations crossed by the boreholes at Soultz-sous-Forêts. With the new Soultz-sous-Forêts stratigraphic data, it has been possible to identify the precise location of the fracture zones intersecting the wells. In fact, the study of the seismic profile and the mud logging data compared to the stratigraphic logs obtained, permitted to confirm the occurrence of these zones. Based on this scientific input involving a well-calibrated borehole, other wells will require less data from the sedimentary section to describe the encountered formations.

\section{Terminology}

In this paper, we define well logs (GR, caliper, density and porosity data) and instantaneous well logging data as mud logging (gas anomalies, rate of penetration of the tool and mud losses). The caliper log measures the internal diameter of the borehole. If the well encounters a fracture zone, the diameter of the well will no longer be circular and may be enlarged, which registers as an anomaly in the caliper log.

An anomaly in temperature indicates that at one precise depth, there is a higher or a lower temperature than in the surrounding rocks. Natural gas emissions are monitored during the drilling phase. The obtained log indicates which formations have gas emission (alkanes from methane to pentane $\left(\mathrm{C}_{1}-\mathrm{C}_{5}\right), \mathrm{CO}_{2}, \mathrm{H}_{2} \mathrm{~S}$ and helium in some wells) and which depths feature anomalies relative to the ambient background. 
The rate of penetration (ROP) of the drill bit indicates the speed at which the bit penetrates the rock, usually reported in $\mathrm{m} / \mathrm{h}$. Normally, the ROP decreases as the drill bit bores into denser formations (Vidal et al. 2015). Raw ROP values are clearly dependent of WOB (weight on bit), RPM (rotation), bit size or mud composition (bulk density). However, for a given drilling section, drillers tried to keep as stable as possible those drilling parameters in order to be able to compare visually and in real-time, the instantaneous raw drilling data. Thus, any raw ROP variation generally fits with facies variations (low ROP) or fracture zone occurrence (high ROP). Spatial correlations between ROP values and fracture zone location or rock facies variation have already been published at Soultz. It mainly showed that high ROP values matched with natural fractures (Traineau et al. 1991). In addition, loss of the entire whole drilling fluid (mud) indicates that the well has intersected a permeable fracture zone. In the Soultz wells, it has been observed during drilling operations that all the mud losses were clearly related to natural fracture zones both in sediments and in granite (Vidal et al. 2015; Genter 1999). Porosity values were quite low even in the sediments. No matrix-porosity aquifer is known in the Soultz sedimentary sequence. The only existing aquifer is controlled by the vertical natural fracture system in which very saline brines have been sampled (Sanjuan et al. 2010).

Other geophysical measurements include the bulk density of the rock formation (recorded in $\mathrm{g} / \mathrm{cm}^{3}$ ) and the neutron porosity (measured in percent). In GPK1, a standard Schlumberger log, calls Compensated Neutron Litho density tool (CND) has been run for measuring, gamma ray, neutron porosity and bulk density in the Triassic layers from 900 to 1400 m depth (Genter et al. 1999). In GPK2, only caliper and gamma ray logs were collected in the sedimentary parts of the well.

The term log cuttings includes macroscopic descriptions of cuttings and cores, field observations and GR well logs. The log cuttings was used to perform this chronolithostratigraphic analysis. Mud logging was used to compare the stratigraphic results to a structural analysis.

In terms of faults, we consider any significant thickness variations in a given layer to indicate the occurrence of a fault. For example, at $641 \mathrm{~m}$ in GPK-1, the unit Marnes à Ovoïdes is only one-third as thick as expected $(18.5 \mathrm{~m}$ instead of the $44 \mathrm{~m})$ because of the presence of a fault. From mud logging based primarily on mud losses, we can define the permeability of a given structure (faults or fracture zones). Faults will also be used for the description of the seismic profile because a profile is supposed to represent only large "faults" with minimum vertical apparent offset of $10 \mathrm{~m}$ (Walsh 1988). Natural fracture or fault permeability is mainly based on mud losses, gas anomalies (Helium, $\mathrm{CO}_{2}$ ) and high ROP values recorded during drilling operations (Vuataz et al. 1990; Vidal et al. 2015). In addition, temperature logs as well as spinner logs combined with acoustic log (BHTV) are a very powerful tool for identifying fractures bearing natural permeability in a Soultz borehole (Evans et al. 2005). Due to the lack of information on fault displacements, the term "fracture zones" is used.

\section{Results and discussion}

Visual methods for the stratigraphic correlations

First of all, the log representing the sedimentary sequence of the well is along the vertical profile (shown to the right side of the log) because it is representing a $1 \mathrm{D}$ well. The 
fracture zones (potentially faults) have been represented on the log with their observed apparent vertical displacement (Figs. 2, 3, 4, 5). These zones were observed based on a change in the stratigraphic succession (units entirely or partially absent or characterized as thinner than expected). For the layer thickness, the correlations are made each time on the right side of the log, represented with the help of a colour scale. As the GR is measured along the total length of each well, the tops and bases of formations are given in measured depth (MD) and not in true vertical depth (TVD), which correspond to the

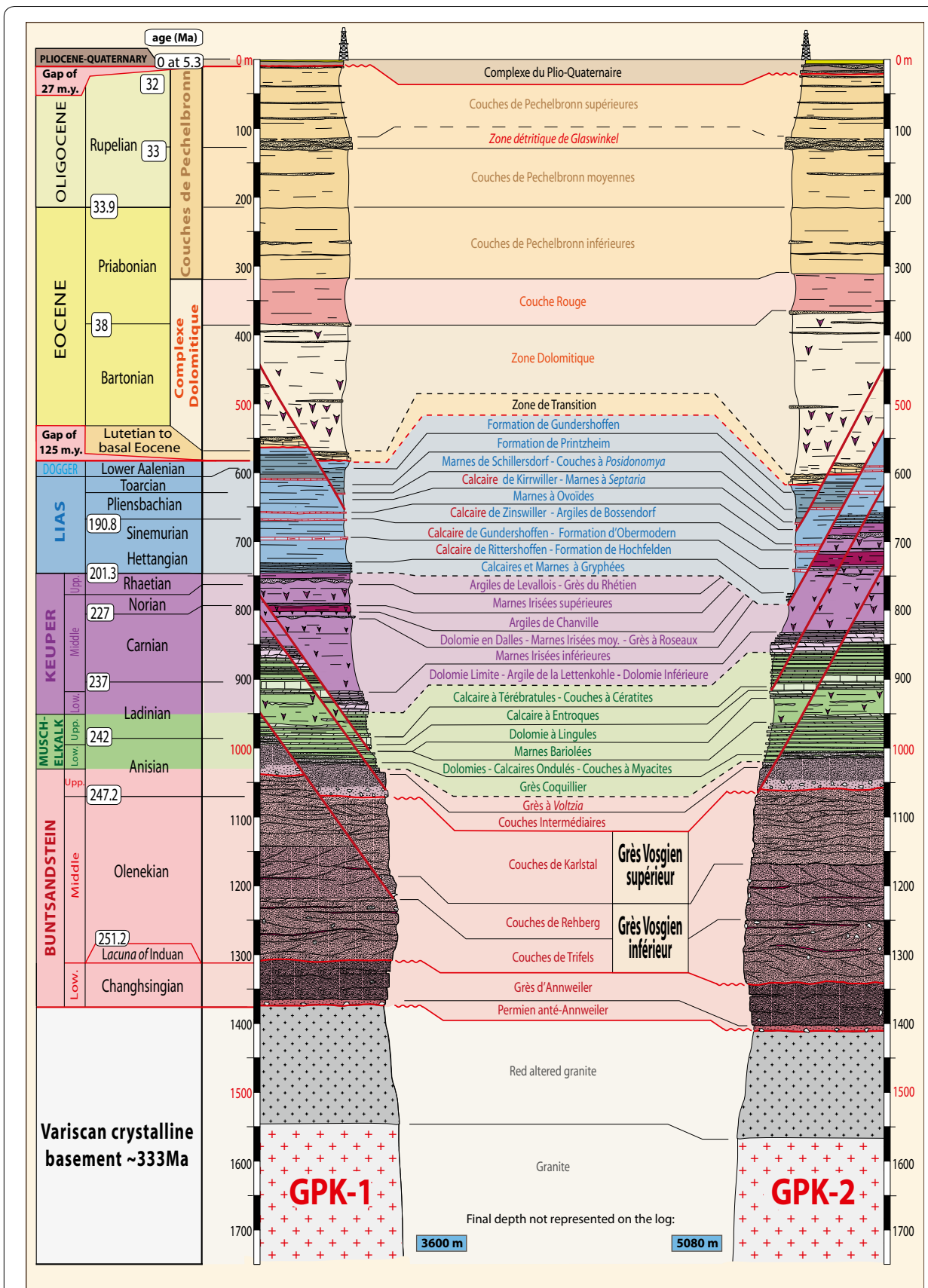

Fig. 4 Complete chrono-lithostratigraphic logs showing all the limits and geological formations encountered in GPK-1 and GPK-2, wells located at Soultz-sous-Forêts 


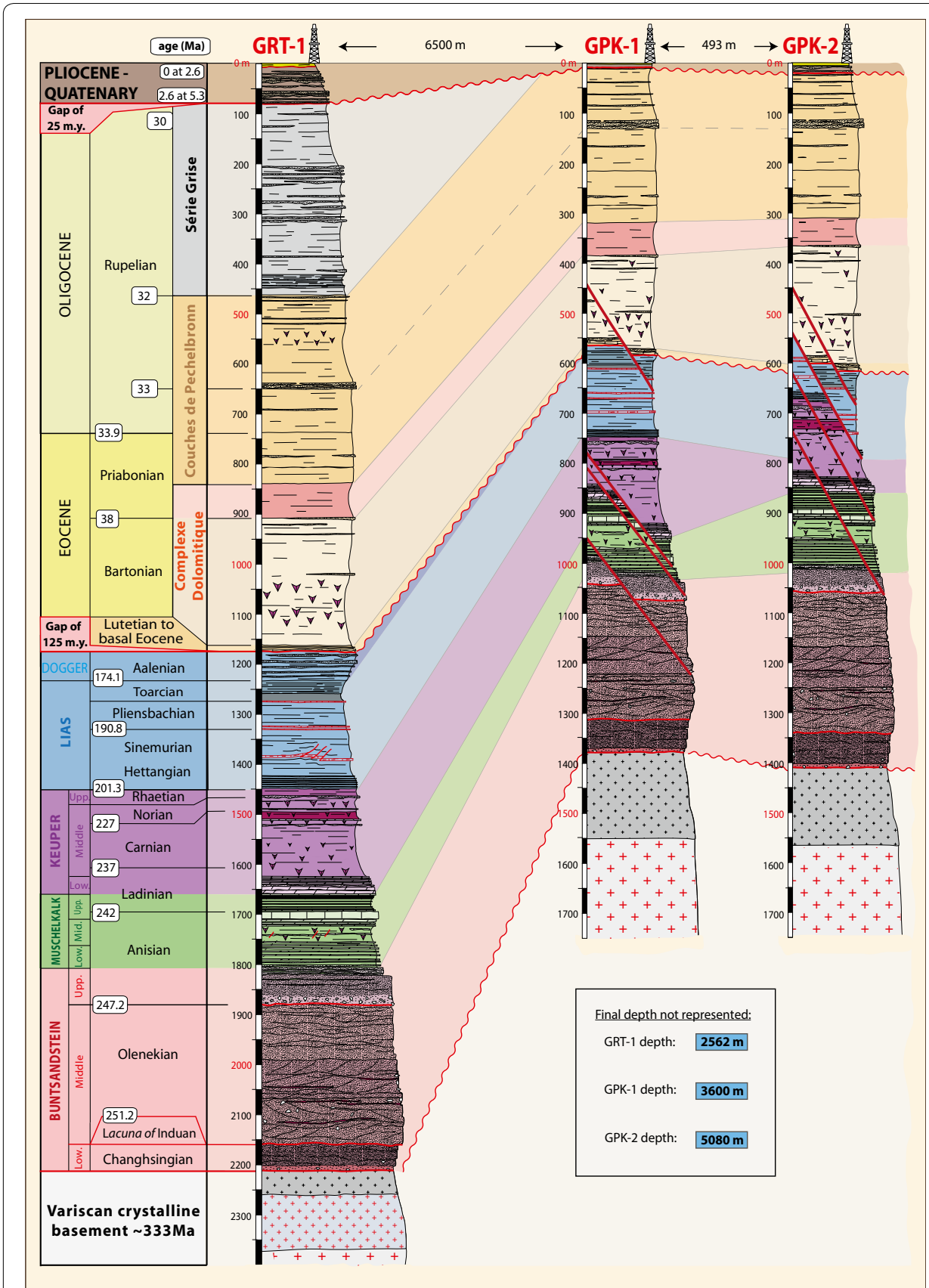

Fig. 5 Well-to-well stratigraphic correlations of the Soultz-sous-Forêts (GPK-1 and GPK-2) and Rittershoffen (GRT-1) wells. The start depth is $0 \mathrm{~m}$, the elevation is about $148 \mathrm{~m}$ for GPK-1, $145 \mathrm{~m}$ for GRT-1 and $164 \mathrm{~m}$ for GPK-2 above sea level

length of the tube/drill and the true thickness of the sedimentary units (representing the vertical depth at the drilling entry point), respectively. As the deviation of the Soultzsous-Forêts wells is low (horizontal shift of $25 \mathrm{~m}$ at the deepest part at the top of the granitic basement between GPK-1 and GPK-2), the thickness in MD is almost the same as in TVD. This is also the case for GRT-1 (Rittershoffen), which has been used for the well-to-well correlation. We do not use the GRT-2 well, which is deviated significantly (up to $37^{\circ}$ ) from the vertical, representing a horizontal shift of $1200 \mathrm{~m}$ at full depth of 
3196 m MD. Moreover, after analyses, GRT-2 has almost the same sedimentary column therefore we could decide to use GRT-1 for the correlations.

To conclude, the logs only show the sedimentary columns. The final depth in the basement of each well is not drawn because this paper is focused on the sedimentary units. The last point is that the GR was measured through the casing in GPK-2 from the surface to a depth of $577 \mathrm{~m}$. After that limit, the GR log was obtained in an open holesection. The casing impacts the resulting log because it reduces the measured GR values but the general shape of the signal is not changed dramatically. For GPK-1, the log was obtained entirely in an open hole-section.

\section{Chrono-lithostratigraphic sequence of Soultz-sous-Forêts (GPK-1 and GPK-2)}

Combining GR logs and cuttings descriptions and making correlations between the wells yielded precise chrono-lithostratigraphic logs at Soultz-sous-Forêts. Figure 2 shows GPK-1 with its GR log and all the chrono-lithostratigraphic information (base and top of each formations and faults occurrences). Figure 3 shows the same information, but for GPK-2, and Fig. 4 shows a well-to-well correlation between GPK-1 and GPK-2. The sedimentary cover is approximately $1375.5 \mathrm{~m}$ thick in GPK-1 and $1411.5 \mathrm{~m}$ thick in GPK-2, and the two wells are located approximately $500 \mathrm{~m}$ apart.

\section{Pliocene-Quaternary}

The sedimentary sequence begins with a thin sandy-clayey complex $(10 \mathrm{~m}$ thick in GPK-1 and $20 \mathrm{~m}$ GPK-2 compared to $71 \mathrm{~m}$ thick at Rittershoffen), corresponding to the Complexe du Plio-Quaternaire. This uppermost unit is poorly documented. For Soultzsous-Forêts, the old interpretation in the masterlog does not provide any information about this complex. In fact, this complex was never actually investigated, but since the development of the Rittershoffen wells (Aichholzer et al. 2015) it has been possible to reinterpret the description given for Soultz-sous-Forêts.

\section{Oligocene and Eocene}

Lower Oligocene to Upper Eocene The Complexe du Plio-Quaternaire is in erosional contact with the underlying Oligocene (early Rupelian). The lower part of the Couches de Pechelbronn supérieures is a homogenous unit composed of calcareous clays intercalated with thin sandstone beds. Correlations inside the Couches de Pechelbronn are not possible, especially between the middle and lower Couches de Pechelbronn. The only objective benchmark is the Zone Détritique de Glaswinkel. This small unit consists of a massive sandstone layer that marks the base of the Couches de Pechelbronn supérieures. It is clearly indicated in the cuttings description by the occurrence of sandstone cuttings and is also clear in the GR $\log$ (Fig. 3) with a sharp peak directed to the left (sudden increase in the "sand/clay" ratio) compared to the sections above and below it. The boundary between the middle and lower Couches de Pechelbronn marks the Oligocene/Eocene boundary, but the precise depth could not be determined.

Eocene: Lower Priabonian to Bartonian The Complexe Dolomitique is composed of two units, the upper Couche Rouge and the lower Zone Dolomitique. The transition from the Couches de Pechelbronn to the Couche Rouge is marked by a sudden increase in red clays 
and a decrease in the calcimetry. This massive red clay unit $(65 \mathrm{~m})$ gradually transitions into the Zone Dolomitique composed of clays, marls and limestones interbedded with thin sandstone beds. The gradual increase in the presence of salt, observed on the calcimetry log, definitively signals the transition to the Zone Dolomitique unit (Aichholzer et al. 2015). The salt and the thin sandstone beds are observed on the GR log because they induces obvious deviations in the signal towards the less radioactive side (peak leftwards compared to the signal above the formation, more homogeneous).

Lutetian to Basal Eocene The Zone de Transition marks the limit between the Cenozoic and the Mesozoic. It is very difficult to objectively define its top and base because of the large lateral facies and thickness variations. Facies heterogeneity could be one of the best terms to define this formation. Because this unit varies from a few metres to tens of metres, from clays to laterites, sandstones or limestones, and from conglomerates to breccias, it is often very difficult to define its precise position solely from the examination of cuttings. The best criterion is the disappearance of saline characteristics from base of the Zone Dolomitique. Secondly, the arrival of lacustrine carbonates, sometimes in very massive beds, is another good criterion. Finally, the occurrence of reworked Jurassic elements definitively signals the transition to the Zone de Transition, even if this reworked material makes it difficult to determine the limit between the Eocene and the Jurassic. The GR signal passes from large amplitudes related to the presence of sulphates (Zone Dolomitique) to a consistent signal (Zone de Transition).

\section{Jurassic and Triassic}

Middle to lower Jurassic (lower Aalenian to Hettangian) The complete Jurassic sedimentary column is approximately $260 \mathrm{~m}$ thick. It is composed mainly of monotonous grey or bluish-grey marls. Defining the formation boundaries is largely based on the study of thin limestone beds commonly located at the base of the formation.

The Jurassic starts at the lower Dogger with the Formation de Gundershoffen and the Formation de Printzheim (Toarcian), composed mainly of clays and silty clays. As the name suggests, the Marnes de Schillersdorf (Toarcian) are composed of black micaceous and silty clays, and argillaceous limestones interbedded with calcareous nodules.

The identification of the Couches à Posidonomya, also called also the Schistes Carton, is based on the very finely laminated appearance and the organic matter-rich content.

The Calcaire de Kirrwiller (Pliensbachian) is a 20-cm-thick limestone bed that is well identified at the transition to the Marnes à Septaria unit due to the well-marked GR signal (strongly directed to the left). This bed features one of the most strikingly negative signals in the Lias.

Because of its marls, the Marnes à Septaria is much more radioactive than the limestone, and the signal therefore increases directly at the transition to this formation. This unit and the Marnes à Ovoïdes are composed of blackish calcareous silty clays. A huge fracture zone (potentially a fault) affecting the Marnes à Ovoïdes is present in both wells (separated by $493 \mathrm{~m}$ ). The thickness of this unit at Soultz-sous Forêts is therefore thinner than it is regionally.

The Calcaire de Zinswiller, which produces another significant left-directed GR signal (GRT-1), is a limestone bed that marks the transition to the Argiles de Bossendorf. This bed is composed of light grey coloured clays, and fossils are common in the field. At 
Soultz-sous-Forêts, after defining the units above and below with the characteristic pattern, it has been possible to estimate the top and base of this formation. In fact, the bank being thinner as at Rittershoffen because of lateral thickness variations, there is no peak on the Soultz-sous-Forêts GR log.

As before, the Calcaire de Gundershoffen (Sinemurian/Hettangian) is a limestone bed marking the transition with the underlying unit, the Formation d'Obermodern, which is composed of laminated calcareous clays that are, sandy to fine-grained sandy, micaceous and pyritic.

The Calcaire de Rittershoffen is the final well-developed limestone bed in the Jurassic section. Already observed but not described in the Oberroedern well (OBR-101), drilled in 1987 this massive limestone is a multi-metric-metre-thick bed (on the order of $5 \mathrm{~m}$ instead of $0.20-1 \mathrm{~m}$ for the other limestone benchmarks in the Lias). The GR signal, strongly directed to the left, is unquestionably the most striking signal in the Jurassic sedimentary column. Moreover, this massive Jurassic limestone is clearly defined as a hard rock on the acoustic borehole log and exhibits a well shape close to the nominal borehole diameter on the caliper log.

Underlying this unit is the Formation de Hochfelden, a silty and marly to calcareous clay unit. The Calcaire et Marnes à Gryphées just below is easily recognizable from the overlying formation because its facies features monotonous and regularly spaced decimetre-scale limestones/marls alternations. This unit yields a specific GR signature with large amplitudes and short frequencies at the base of the Lias, and the entire signal is less radioactive than the other unit of Jurassic (more leftwards).

Keuper (Rhaetian to Upper Ladinian) The Keuper is composed of six formations that are entirely, present in GPK-1 but affected by fracture zones in GPK-2 (Fig. 4). Compared to the Jurassic, the Keuper facies are red and green in colour and often contain anhydrite. This unit contrasts sharply with the grey-dominated colour of the Jurassic, which greatly aids the defining of the boundaries.

It starts with the Argiles de Levallois, which is composed of red to black silty clays covering the Grès $d u$ Rhétien, a sandstone formation that is locally conglomeratic and easily observed on the GR log because the signal features a strong leftwards peak.

Below, the Marnes Irisées supérieures is composed mainly of clays, calcareous clays, argillaceous marls and dolomitic clays interbedded with dolomite bed.

The Argiles de Chanville unit is composed of red clays, slightly micaceous and finely dolomitic. In addition to the cuttings description, the GR log shows a huge shift to the right (radioactive) because of the presence of these clays.

Evidence for the presence of the Dolomie en Dalles is lacking. Based on the work of Ménillet (2015), this unit has likely been replaced in this area by a massive anhydrite unit, which produces a large leftward GR signal.

The Marnes Irisées moyennes is composed of coloured marls similar to the marls of the Marnes Irisées supérieures. Below this, the Grès à Roseaux is undoubtedly the best benchmark in the Keuper. It is characterized as a fluviatile phase inside a lagoon and evaporitic phase during middle Keuper.

The Marnes Irisées inférieures is composed of clays and is locally calcareous and dolomitic with an abundant presence of gypsum/anhydrites. 
The lower Keuper called Lettenkohle is composed of three units from top to base: the Dolomie Limite; the Argile de la Lettenkhole; and the Dolomie Inférieure. The Dolomie Limite (several decimetres in thickness) is, poorly developed and is, composed of shelly dolomitic beds. The transition is highly visible between the two units because the Dolomie Limite has a very week GR signal (to the left) compared to the Marnes Irisées inférieures due its non-radioactive dolomitic beds. The Argile de la Lettenkhole, with its clays, has a very strong positive signal (to the right of the GR $\log$ ). This last unit is composed of alternating marls and dolomites, with some decametric decametre-scale sandstone beds close to the base. Hence, the GR signal increases again to the radioactive side. The Dolomie Inférieure is a very massive and compact dolomitic unit, with little radioactivity (strongly directed to the left). The amplitudes of the GR signals from the Argile de la Lettenkohle and the Dolomie Inférieure are the strongest in the entire sedimentary column.

Muschelkalk (lower Ladinian to upper Anisian) The Muschelkalk begins with the Calcaire à Térébratules, a formation composed of two massive slightly dolomitic limestone beds (up to $3 \mathrm{~m}$ thick). Below, the Couches à Cératites is composed of a homogenous unit of alternating limestones and marls.

In the Couches à Cératites, from top to base, the GR signal slowly increases before decreasing again towards the underlying to the Calcaire à Entroques. This "back and forth" is a characteristic pattern of this formation indicating the (deepening and shallowing of facies). Below, the Calcaire à Entroques is the most massive limestone without marls in the sedimentary column.

The underlying Dolomie à Lingules is composed of dolomitic limestones and dolomitic marls.

The Marnes Bariolées is characterized by red to grey sandy clays local dolomitic, and dolomitic marls with large amounts of anhydrites. This complex is composed of three formations grouped together: the Dolomies, Calcaire Ondulés, and Couches à Myacites formations contain alternating marls, marly dolomites and dolomites (Aichholzer et al. 2015) (Figs. 2, 3, 4). The final Muschelkalk unit is the Grès Coquillier, a shelly sandstone to dolomitic sandstone interbedded with clayey marl beds. As shown in the figures, the wells are affected by fracture zones in the Muschelkalk.

Buntsandstein (Lower Anisian to Changhsingian) The Buntsandstein forms the base of the Triassic sequence. It is composed of seven dominantly red-coloured sandstone units. At the top of the Buntsandstein formation, the Grès à Voltzia unit is the first light-red micaceous sandstone, so the transition to the Buntsandstein is easily recognizable with the change in colour and high content quartz. In addition, the transition is marked by the presence of the most radioactive peak of the entire sedimentary column. The GR increases from the middle of Keuper to the base of the Buntsandstein formation. The highest GR signal is quite similar in all the wells and marks the transition to the Buntsandstein. From this peak, the GR starts to decrease again.

Below the very fine-grained argillaceous sandstone, the Couches Intermédiaires features a coarser-grained texture and a colour progressively changing from light red to red. The clay percentage decreases progressively downwards through the formation, producing a GR signal that decreases. 
The EPS-1 drill-core analysis of the Buntsandstein was used to identify the boundaries of the Grès Vosgien. This unit is composed of the Couches de Karlstal (poorly cemented aeolian facies), the Couches de Rehberg (fluvial facies) and the Couches de Trifels (fluvial facies). These pink to red-brown sandstone formations are very similar to each other and the proportion of feldspar is basically the same from the top to the base of these units. The GR $\log$ has an overall consistent value, except for the transition between the Couches de Rehberg and Couches de Trifels, which is characterized by three well-developed (up to $20 \mathrm{~cm}$ thick) red clays that produce rightwards-directed peak in both GR logs and that are evident in the EPS-1 cores.

The Grès d'Annweiler and the Permien ante-Annweiler are both Upper Permian units but are known as the Buntsandstein Inférieur. The GR signature of these units is characteristically more radioactive than that of the Grès Vosgien because they are more clayey, and the lithologic transition features a distinctive colour change. In many respects, (GR signature and fine-grained sandstone lithology), these Permian units are quite similar to the Grès à Voltzia unit. Indeed these Permian sandstones are relatively dark, from dark red to reddish brown.

Both wells (GPK-1 and GPK-2) show the presence of fracture zones at the transition between the Couches Intermédiaires and the Couches de Karlstal, and in GPK-1, another fracture zone is present in the Couches de Trifels (Fig. 4).

\section{Palaeozoic granitic basement}

The granitic basement is obvious in at the GR log. When the signal is continuously directed to the right side of the $\log$, it means that the unit is very radioactive. The most radioactive formation is the granitic basement. The sedimentary cover may have radioactive formations, but none as strongly radioactive as granite. Therefore, the large shift to the right is associated with the transition to the Palaeozoic basement at $1375.5 \mathrm{~m}$ for GPK-1 and $1411.5 \mathrm{~m}$ for GPK-2.

\section{Structural correlations between the geothermal Soultz-sous-Forêts wells}

With such well-calibrated boreholes in the sedimentary part, it has been possible to correlate the different fracture zones observed from stratigraphic analyses with a structural analysis (Vidal et al. 2015). In fact, some major zones have been highlighted with the well-to-well correlation between Soultz-sous-Forêts and Rittershoffen, which has highlighted some thickness variations not always associated to lateral variations. GPK-1 is affected by four faults, one in the Lias, one in the Muschelkalk and two in the Buntsandstein (Fig. 2). GPK-2 is also affected by four normal faults, one in the Lias, one in the Keuper, one in the Muschelkalk and one in the Buntsandstein (Fig. 3). Vidal et al. (2015) defined six facture zones in GPK-1 and eight in GPK-2, characterized as either permeable or sealed based on drilling data. The tables below present the different types of data that were used for the observations: the mud logging and the log cutting, and for each fracture zones what is the observation given by the data.

\section{Faults observed on the seismic profile}

Based on the seismic profile (Fig. 6) (Cautru 1988, redrawn by Koelbel et al. 2011), the depth of each fault was given. In addition at each depth the mud logging and the log 

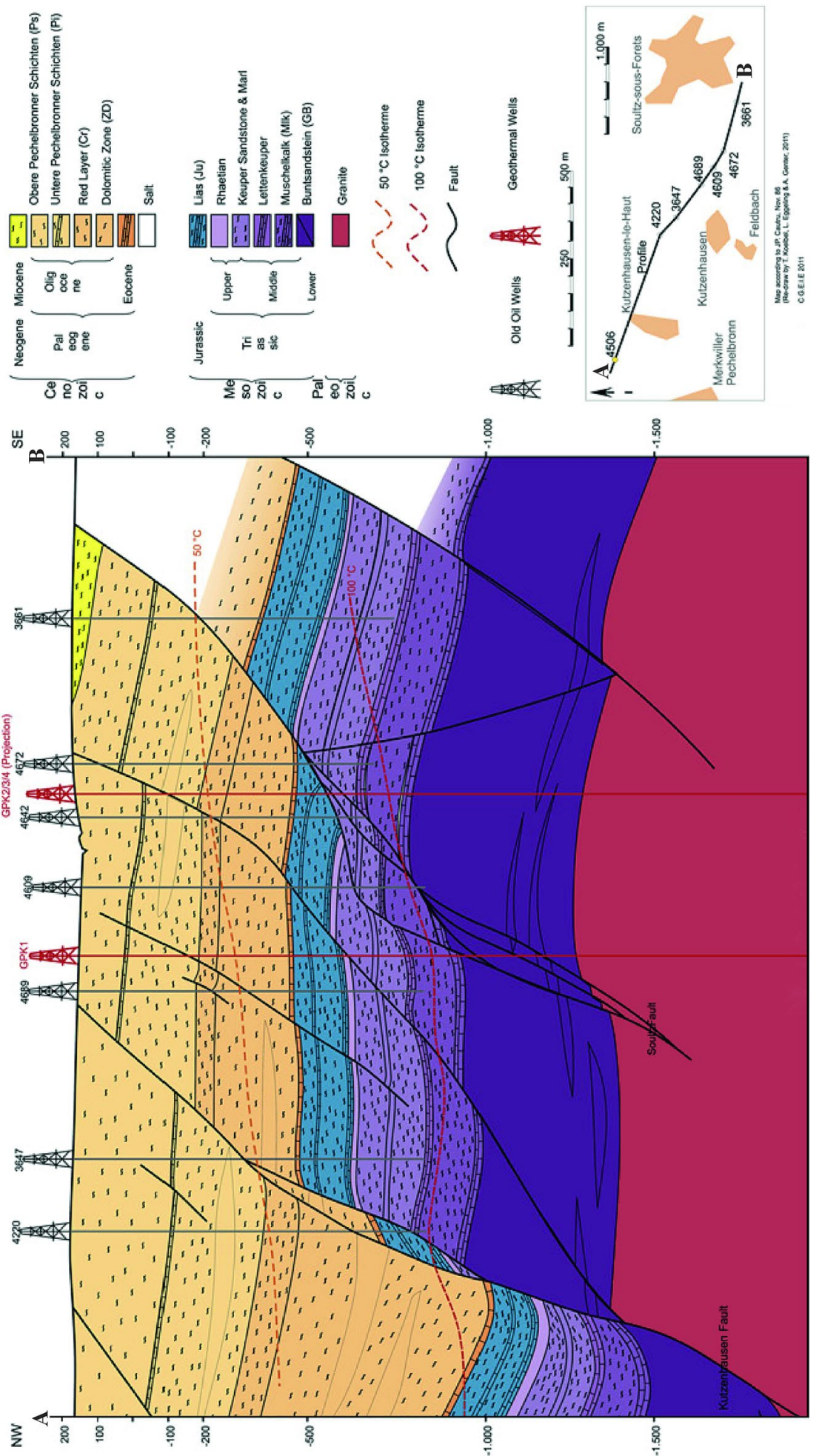

Fig. 6 Seismic reflection profile interpreted in term of geological cross section. The oil wells and the geothermal boreholes GPK-1, GPK-2, GPK-3 and GPK-4 are projected on this profile 
cutting were taken into consideration in order to evaluate whether the zones were previously observed in the other well data (Table 1).

\section{Fracture zones observed on mud logging or log cutting}

Some fracture zones were not observed in the seismic profile but were identified with the lithostratigraphic well-to-well correlation between Soultz-sous-Forêts and Rittershoffen (Figs. 2, 3). In addition, some others anomalies were observed in the mud logging data (Vidal et al. 2015). Therefore, the tables below present only these fracture zones in addition to those before (Table 2).

Table 1 Faults observed on the seismic profile analysed in mud logging and log cutting

\begin{tabular}{|c|c|}
\hline Depth & \\
\hline \multirow[t]{4}{*}{ 300 m } & GPK-1 \\
\hline & Very local fault with almost no apparent fault offset \\
\hline & Mud logging: nothing observed \\
\hline & Log cutting: nothing observed \\
\hline \multirow[t]{3}{*}{$\sim 750 \mathrm{~m}$} & Local fault from the surface to the Kutzenhausen boundary fault which has a $100 \mathrm{~m}$ fault offset \\
\hline & Mud logging: caliper and temperature anomalies \\
\hline & Log cutting: nothing observed \\
\hline \multirow[t]{3}{*}{$\sim 1083 \mathrm{~m}$} & $\begin{array}{l}\text { Soultz-sous-Forêts Fault from the surface down into the granitic basement with approximately } \\
100 \text { m cumulated fault offset }\end{array}$ \\
\hline & $\begin{array}{l}\text { Mud logging: between } 1042 \text { and } 1049 \text { m several caliper anomalies, variations in neutron porosity, } \\
\text { temperature and bulk density }\end{array}$ \\
\hline & Log cutting: Couches Intermédiaires reduced about 29.5 m in comparison with Rittershoffen \\
\hline \multirow[t]{2}{*}{$\sim 1116 \mathrm{~m}$} & Mud logging: nothing observed \\
\hline & Log cutting: nothing observed \\
\hline \multirow[t]{2}{*}{$\sim 1233 \mathrm{~m}$} & $\begin{array}{l}\text { Mud logging: anomalies in temperature and ROP, and between } 1219 \text { and } 1240 \mathrm{~m} \text { total mud losses } \\
\text { which involves a permeable fault at } 1219 \mathrm{~m}\end{array}$ \\
\hline & $\begin{array}{l}\text { Log cutting: anhydrites filling, Couches de Rehberg twice reduced in comparison with Rittershoffen } \\
(33 \text { m instead of } 79.5 \text { m) }\end{array}$ \\
\hline \multirow[t]{3}{*}{$\sim 1316 \mathrm{~m}$} & Mud logging: nothing observed \\
\hline & Log cutting: nothing observed \\
\hline & GPK-2 \\
\hline \multirow[t]{3}{*}{ 266 m } & Local fault from the surface to the Kutzenhausen boundary Fault with $100 \mathrm{~m}$ fault offset \\
\hline & Mud logging: nothing observed \\
\hline & $\begin{array}{l}\text { Log cutting: a fault with a small vertical offset in an unconsolidated unit (Couches de Pechelbronn) is } \\
\text { not necessary visible, moreover it is the uppermost unit therefore already eroded at the top }\end{array}$ \\
\hline \multirow[t]{3}{*}{ 708 m } & $\begin{array}{l}\text { Soultz-sous-Forêts Fault from the surface down into the granitic basement with approximately } \\
330 \text { m cumulated fault offset }\end{array}$ \\
\hline & Mud logging: little gas peak \\
\hline & Log cutting: nothing observed \\
\hline \multirow[t]{2}{*}{$\sim 733 \mathrm{~m}$} & Mud logging: nothing observed \\
\hline & Log cutting: nothing observed \\
\hline \multirow[t]{2}{*}{$\sim 766 \mathrm{~m}$} & Mud logging: nothing observed \\
\hline & Log cutting: nothing observed \\
\hline
\end{tabular}


Table 2 Fracture zones observed through the stratigraphic analysis (log cutting) analysed with the mud logging and on the seismic profile

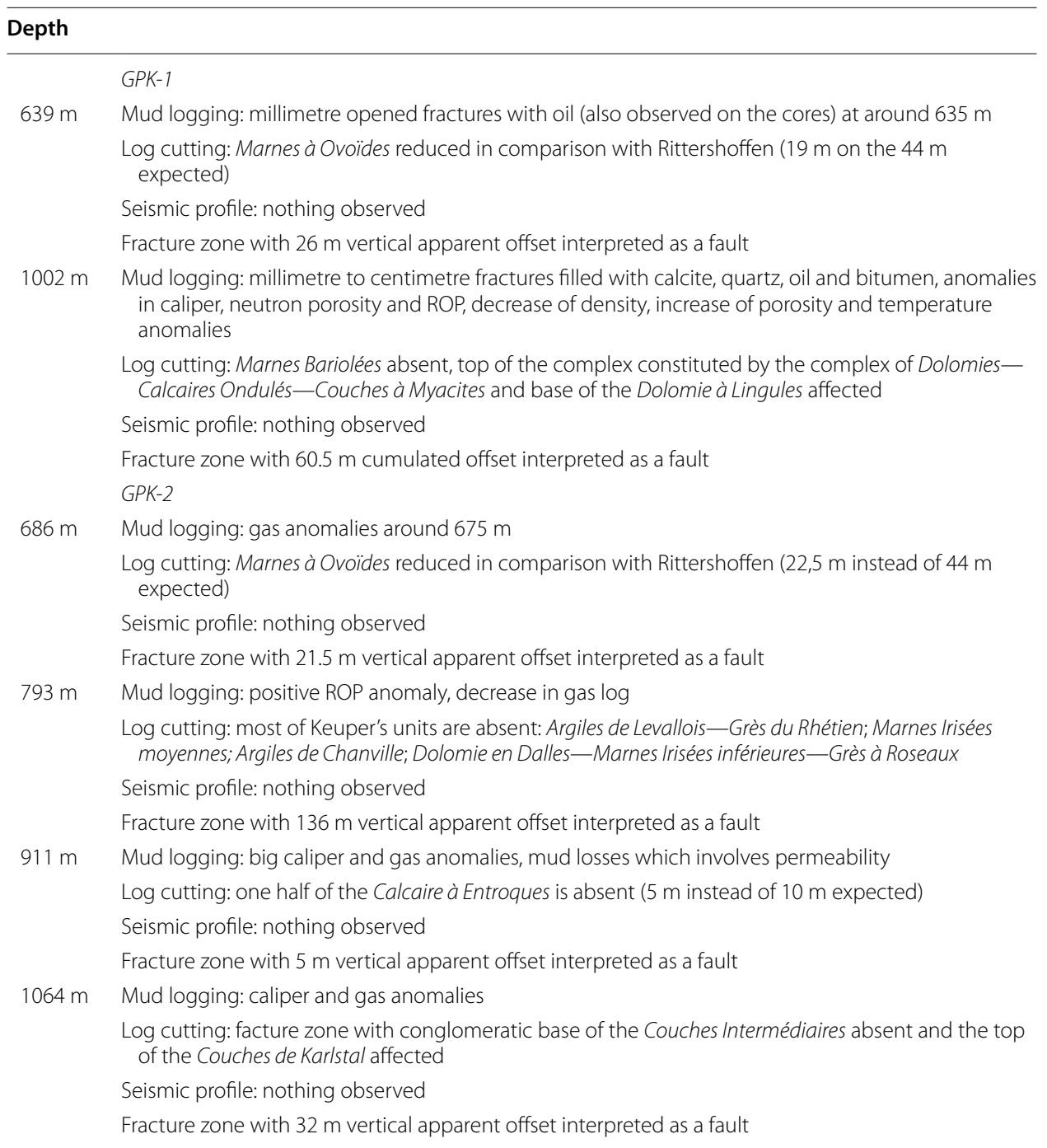

\section{The Soultz-sous-Forêts (GPK) wells compared with the wells of Rittershoffen (GRT)}

Metre by metres, from the basement to the surface, the sequence observed at Soultzsous-Forêts is similar to that of Rittershoffen in terms of units but not in terms of thickness (Fig. 5). In fact, thickness variations are induced by erosion or associated with fracture zones. Therefore, some units are reduced or absent.

\section{Thickness variations in formations explained by erosion}

At Soultz-sous-Forêts, one of the main differences lays in the fact that part of the tertiary and the quaternary formations are significantly reduced by erosion. Compared to GRT, the wells GPK-1 and GPK-2 lack parts of the Complexe du Plio-Quaternaire. Likewise, they lack the whole Série Grise and the upper part of the Couches de Pechelbronn, both layers from the Oligocene that together represent a cumulative thickness of approximately $524 \mathrm{~m}$ in GPK-1 and $532 \mathrm{~m}$ in GPK-2. The detrital Glaswinkel sequence 
marks the bottom of the Couches de Pechelbronn supérieures. At Soultz-sous-Forêts (GPK-1 and GPK-2), this detrital benchmark is approximately $20 \mathrm{~m}$ thick, which is twice the thickness obtained at Rittershoffen (GRT-1). This lateral thickness variation from $20 \mathrm{~m}$ at Soultz-sous-Forêts to $9 \mathrm{~m}$ at Rittershoffen is explained by the proximal/distal evolution of detrital input from the western shoulder of the rift (Duringer 1988). Due to lateral thickness variations, the Zone Dolomitique is thinner at Soultz-sous-Forêts than at Rittershoffen. The reduction is $65.5 \mathrm{~m}$ for GPK-1 and $18.5 \mathrm{~m}$ GPK-2. In fact, Soultzsous-Forêts is located close to the rift border therefore the Zone Dolomitique is not as thick as at Rittershoffen, which is located more centrally in the basin. Another great difference lies at the Mesozoic/Cenozoic unconformity.

Compared to Rittershoffen the erosion of the Jurassic upper part is more extensive in the sedimentary column of Soultz. Hence, many Dogger units are absent, removed during late Jurassic uplift and the Cretaceous/early Tertiary exposure. Compared to GRT-1 (Rittershoffen), the Soultz-sous-Forêts area lacks the first units of Jurassic (approximately $53 \mathrm{~m}$ ). In sum, compared with the Rittershoffen wells, the Soultz-sous-Forêts area lacks approximately $642.5 \mathrm{~m}$ in GPK-1 and $604 \mathrm{~m}$ in GPK-2 in the upper part of the sedimentary column. Finally, in GPK-2, the Calcaire à Térébratules-Couches à Cératites section is $12.5 \mathrm{~m}$ thicker. This can be explained by the fact that this unit is mainly composed of marls, which can experience considerable compaction effects, leading to lateral thickness variations.

\section{Fracture zones and effects on associated units reduction}

In addition to the erosion described above, several major fracture zones are present in both of the Soultz-sous-Forêts wells (GPK-1 and GPK-2). Two of them affect the Marnes à Ovoïdes (Jurassic) in GPK-1 and GPK-2, which lacks two-thirds of it thickness (Fig. 5). The thicknesses of the other Jurassic units are approximately the same, with a few variations being caused by weak lateral thickness variations.

Six other fracture zones (potentially faults) were observed to affect the Muschelkalk and the Buntsandstein units in GPK-1, and the Keuper, Muschelkalk and Buntsandstein in GPK-2. Compared to Rittershoffen, GPK-1 does not contain the entire sequence of the Middle Muschelkalk, which is reduced by approximately one-third. In fact, the $-40 \mathrm{~m}$ of the Marnes Bariolées are entirely missing, and the base of the Dolomie à Lingules is affected. In the Buntsandstein, half of the Couches Intermédiaires is missing. In GPK-2, a considerable portion of the Keuper is missing because the Argiles de Levallois-Grès du Rhétien, the Marnes Irisées supérieures, the Argiles de Chanville and the Dolomie Limite-Argile de la Lettenkhole-Dolomie Inférieure are absent. The Upper Muschelkalk formation is lacking $5 \mathrm{~m}$ of the Calcaire à Entroques which is half of the unit. In the Buntsandstein, faulting has removed the conglomeratic base of the Couches Intermédiaires and has affected the top of the Couches Intermédiaires, which is missing $27 \mathrm{~m}$. In both wells, for all the other units of the sedimentary sequence, the thicknesses are almost the same. The small variations represent lateral variations in these units.

In summary, the faults affecting the units decrease the thickness of the sedimentary column by $161.5 \mathrm{~m}$ in GPK-1 and of $191.5 \mathrm{~m}$ in GPK-2. Knowing that the basement is at $1375.5 \mathrm{~m}$ in GPK-1, $1411.5 \mathrm{~m}$ in GPK-2 and $2198 \mathrm{~m}$ in GRT-1 (Rittershoffen), we know that $822.5 \mathrm{~m}$ are missing from GPK-1 and $786.5 \mathrm{~m}$ from GPK-2 (Fig. 5). The thickness 
reduction due to erosion $(642.5 \mathrm{~m})$ and faults $(161.5 \mathrm{~m})$ is equal to $804 \mathrm{~m}$ in GPK-1, which means that $18.5 \mathrm{~m}$ are attributable to slight lateral variations in the units. For GPK-2, $795.5 \mathrm{~m}$ are missing from the sedimentary column. Without the thickening of $12.5 \mathrm{~m}$ (Calcaire à Térébratules-Couches à Cératites), the reduction is $783 \mathrm{~m}$ (erosion: $604 \mathrm{~m}$, faults: $191.5 \mathrm{~m}$ ), which means that $3.5 \mathrm{~m}$ are attributable to lateral variations.

\section{Conclusion from the structural and stratigraphic analyses}

Some faults identified with the help of the seismic profile are not observed in the wells. In fact, the Soultz-sous-Forêts fault has a rather complex geometry (Sausse et al. 2010). A seismic profile, representing a $2 \mathrm{D}$ visualization, does not necessarily show the faults crossing a well. Depending on the geometric features of the fault, the orientation of the profile is critical. Moreover, as the trajectories are projected along the seismic profile, there may be some depth differences associated with the faults or the layers cross-section between the seismic representation and the actual borehole data.

The fault located at $641 \mathrm{~m}$ in GPK-1 and $686 \mathrm{~m}$ in GPK-2 affects the same unit in both of the wells: the Marnes à Ovoïdes. The same apparent offset is observed because in each well, two-thirds of the unit are missing (the units are 19 and $22.5 \mathrm{~m}$ thick in GPK-1 and GPK-2, respectively, as against $45 \mathrm{~m}$ in the case of Rittershoffen). This means that it could be the same fault affecting this Jurassic unit at Soultz-sous-Forêts. In GPK-1-the three deepest faults (1002, 1049 and $1219 \mathrm{~m}$ ) could correspond to the imbrication of the Soultz-sous-Forêts fault branches, as observed on the seismic profile. In GPK-2, the three deepest faults (793, 911 and $1064 \mathrm{~m})$ could also be the Soultz-sous-Forêts fault branches. In fact, due to the complex geometry of this fault, these branches are observed at a shallower depth than at GPK-1. Moreover, on the seismic profile, we observe a projection of the well, which also induces some geometric approximations. Therefore, we did not observe anything at the depth estimated for the Soultz-sous-Forêts fault in GPK-2 because it was not at the exact same depth (GPK-2 being projected). The top of the granitic basement is deeper at GPK-2 than at GPK-1; thus, we observe a general 'deepening' of this fault surface to the south.

To go further into this 2D structural analysis, it could be very interesting to construct a $3 \mathrm{D}$ geometric model considering the real trajectories of the wells and the actual 3D geometry of the faults.

\section{Conclusions}

The analyses of the drill cuttings from the doublet of geothermal wells GRT-1, GRT-2) at Rittershoffen combined with a geological calibration on regional outcrops provided a very detailed and complete chrono-lithostratigraphic log. Therefore, the Rittershoffen's logs have been used as a baseline to reinterpret the sedimentary succession in the GPK-1 and GPK-2 boreholes at Soultz-sous-Forêts, which were poorly investigated in the past.

This geological studies based on surveys logs, field work, geophysical data and cores/ cuttings from the geothermal wells at Soultz-sous-Forêts and Rittershoffen provided both a chrono-lithostratigraphic log of the historical Soultz-sous-Forêts wells and lateral well-to-well comparisons between the old (Soultz-sous-Forêts 1987) and recent (Rittershoffen 2014-2015) geothermal wells. 
One of the first results at Soultz-sous-Forêts compared to Rittershoffen is the substantial erosion of the Tertiary and Quaternary formations. The Soultz-sous-Forêts wells lack the whole Série Grise, the upper part of the Couches de Pechelbronn (Oligocene) and almost the entire Complexe $d u$ Plio-Quaternaire formations, which together represent a cumulative thickness of approximately $444 \mathrm{~m}$.

A second difference is present at the Mesozoic/Cenozoic unconformity. The erosion of the upper part of the Jurassic is more marked in the Soultz sedimentary columns, and several units of the Dogger are absent, removed during Cretaceous/early Tertiary exposure at the surface. Compared to Rittershoffen, the Soultz sedimentary column lacks approximately $35 \mathrm{~m}$ of the upper Jurassic formations (Argiles Sableuses and Formation de Schalkendorf).

Finally, the occurrence of two normal faults that affect the Lias and Muschelkalk units in the GPK-1 borehole was highlighted. The fault in the Lias led to the disappearance of the majority of the Marnes à Ovoïdes formation. The fault observed in the Muschelkalk is associated with the removal of the complete Marnes Bariolées and the lower part of the Dolomie à Lingules. In GPK-2, we identified four normal faults (one present in both wells, and three others only present in one well) - that are present in the Lias, Muschelkalk and Keuper. The sum total of the thickness missing from the stratigraphic column of Soultz-sous-Forêts, compared to the one of Rittershoffen, is approximately $790 \mathrm{~m}$.

Thus, the detailed analysis of the lithostratigraphic units calibrated against the Rittershoffen geothermal wells is a very powerful technique for improving the geological knowledge. An additional method includes the analysis of 2D seismic profiles in this part of the URG, which is very interesting in terms of geothermal project development. Moreover, with this stratigraphic work, it has been possible to highlight some faults associated with important thickness variations. With a structural analysis in combination with well data (mud logging) and seismic profiles, the faults were precisely located with respect to depth in each well. One of the major results is the impact of the major Soultz-sous-Forêts Fault, which affects different units because of the complex geometry of its branches. The Soultz-sous-Forêts fault branches are located at 1002, 1049, $1219 \mathrm{~m}$ in GPK-1 and at 793, 911 and $1064 \mathrm{~m}$ in GPK-2. In these wells, a common fault has also been observed in the Jurassic at $639 \mathrm{~m}$ in GPK-1 and $686 \mathrm{~m}$ in GPK-2 base on the same vertical offset in the same unit. The structural knowledge of the sedimentary portions of the Soultz-sous-Forêts wells was seriously improved by this lithostratigraphic re-interpretation using mainly well-to-well correlations and gamma ray log responses. In the Soultz-sous-Forêts geothermal wells, existing faults information from seismic scale and fracture zone locations derived from various drilling data were adequately combined with the new stratigraphic limits. Then, the structural scheme of the Soultz wells has been improved by highlighting the main fault traces.

\section{Authors' contributions}

CA and PhD analysed all the data available (GRT-1, GRT-2, GPK-1 to 4, EPS-1 and field works) and interpreted the sedimentary cover from the top to the basement. SO and PhD have brought significant geological assistance for the comparison of the formation boundaries between GRT-1 and EPS-1, especially for the Buntsandstein. CA and AG interpreted the newly stratigraphic results in the Soultz-sous-Forêts wells in terms of faults and fracture zones occurrences by comparison with borehole mud logging data and seismic profile interpretation. This contribution permitted the correlations in the Buntsandstein between GRT and GPK wells. All authors read and approved the final manuscript. 


\begin{abstract}
Author details
${ }^{1}$ Institut de Physique du Globe de Strasbourg (IPGS), UMR 7516, CNRS-Université de Strasbourg EOST, 1 rue Blessig 67084 Strasbourg Cedex, France. ${ }^{2}$ GEOLOG France SAS, 9/11 allée de I'Arche, La Défense, 92671 Courbevoie Cedex, France. ${ }^{3}$ ES-Géothermie, Le Belem -5 rue de Lisbonne, 67500 Schiltigheim, France.
\end{abstract}

\title{
Acknowledgements
}

We thank the LabEx G-EAU-THERMIE PROFONDE (the University of Strasbourg, IPGS/UMR 7516) which is co-funded by the French government under the program "Investissements d'Avenir" for the several years of financial support. We also thank the GEIE Exploitation Minière de la Chaleur and the ECOGI/ES group (Exploitation de la Chaleur d'Origine Géothermale pour l'Industrie/Electricité de Strasbourg) for providing a complete and precious geological and geophysical databases, respectively, for the Soultz-sous-Forêts and Rittershoffen wells.

Also, the authors would like to thank the AJE experts for the English language review and the anonymous reviewers for their contributions and the improvement of the earlier version of this article.

\section{Competing interests}

The authors declare that they have no competing interests.

Published online: 07 October 2016

\section{References}

Aichholzer C, Duringer Ph, Orciani S, Genter A. New stratigraphic interpretation of the 28 year old GPK-1 geothermal well of Soutlz-sous-Forêts (Upper Rhine Graben, France). In: 4th European geothermal workshop, 19-20 Oct 2015, Strasbourg; 2015

AGR Pioneering Achievements. Open hole wireline logging, self learning module. Tracs International GEO4250, Spring 2008. 2013. Available via UiO Universitetet i Oslo. http://www.uio.no/studier/emner/matnat/geofag/GEO4250/v08/ Open_Hole_Wireline_logging.pdf.

Bauer JF, Meier S, Philipp SL. Architecture, fracture system, mechanical properties and permeability structure of a fault zone in Lower Triassic sandstone, Upper Rhine Graben. Tectonophysics. 2015;647-648:132-45. doi:10.1016/j. tecto.2015.02.014.

Baujard C, Genter A, Graff JJ, Maurer V, Dalmais E. ECOGI a new deep EGS project in Alsace, Rhine graben, France. In: Proceedings World Geothermal Congress 2015, Melbourne; 2015. Accessed 19-25 April 2015.

Berger JP, Reichenbacher B, Becker Z, Grimm M, Grimm K, Picot L, Storni A, Pirkenseer C, Derer C, Schaefer A. Paleogeography of the Upper Rhine Graben (URG) and the Swiss Molasse Basin (SMB) from Eocene to Pliocene. Int J Earth Sci. 2005:94:697-710. doi:10.1007/s00531-005-0475-2.

Bergerat F. Déformations cassantes et champs de contrainte tertiaires dans la plate-forme européenne. Paris: Université Paris 6; 1985. p. 359.

Blanc-Valleron MM. Les formations paléogènes évaporitiques du bassin potassique de Mulhouse et des bassins septentrionaux d'Alsace. Strasbourg: Université de Strasbourg; 1990. p. 350.

Blumenroeder J. Le pétrole en Alsace. Abh Geol Landesamt Baden-Würtbg. 1962;4:41-2.

Brun JP, Wenzel F. Crustal-scale structure of the southern Rhinegraben from ECORS-DEKORP seismic reflection data. Geology. 1991;19:758-62. doi:10.1130/0091-7613(1991)019.

Carlier C, Royer JJ, Flores EL. Convective heat transfer around the Soultz-sous-Forêts geothermal site (Rhine Graben). In: BRGM Eds doc. 223 Vlth Int. Symposium continental scientific drilling programs, Paris; 1992.

Cautru JP. Coupe géologique passant par le forage GPK-1 calée sur la sismique réflection. Institut Mixte de Recherches Géothermiques, BRGM; 1988.

Clapp FG. Oil and gas possibilities of France. AAPG Bull. 1932;16:1092-143.

Datalog Technology Ltd. Final GPK-2 well report for socomine, main technical report and appendices. 1995.

Desbrandes R. Encyclopedia of well logging. Paris: Editions OPHRYS; 1985.

Dezayes C, Gentier S, Genter A. Deep geothermal energy in Western Europe: the Soultz project, final report BRGM/RP54227-FR. 2005.

Duringer Ph. Les conglomérats des bordures du rift Cénozoïque Rhénan. Dynamique sédimentaire et contrôle climatique. Strasbourg: Université de Strasbourg; 1988. p. 287.

Duringer Ph, Gall JC. Morphologie des constructions microbiennes en context de Fan-delta oligocène. Exemple du rift rhénan (Europe occidentale). Paleogeogr Paleoclimatol Paleoecol. 1994;107(1-2):35-47.

Duringer Ph. Dynamik der detritischen Ablagerungen am Rande des Oberrheingrabens (Obereozän-Unteroligozän) (Exkursion G am 21 April 1995). Jber Mitt Oberrhein Geol Ver NF. 1995;77:167-200. doi:10.1127/jmogv/77/1995/167.

Duringer Ph. Les champs de fractures des collines sous-vosgiennes. In: Gely JP, Hanot F, éditors. Le Bassin de Paris, un nouveau regard sur la géologie. Paris: cinquantenaire de l'Association des Géologues du Bassin de Paris 135; 2014.

Edel JB, Schulmann K, Rotstein Y. The Variscan tectonic inheritance of the Upper Rhine Graben: evidence of reactivations in the Lias, Late Eocene-Oligocene up to the recent. Int J Earth Sci. 2007:96:305-25. doi:10.1007/s00531-006-0092-8.

Evans KF, Genter A, Sausse J. Permeability creation and damage due to massive fluid injections into granite at $3.5 \mathrm{~km}$ at Soultz: part 2-critical stress and fracture strength. J Geophys. 2005; doi:10.1029/2004JB003168.

Fiet N, Gorin GE. Gamma-ray spectrometry as a tool for stratigraphic correlations in the carbonate-dominated, organicrich, pelagic Albian sediments in Central Italy. Eclogae Geol Helv. 2000;93:175-81.

Fertl WH. Gamma-ray spectral data assits in complex formation evaluation. Log Anal. 1979;20:05.

Genter A. Geological and well-logging data collected from 1987 to 1989 at the HDR site Soultz-sous-Forêts. BRGM Open File Rep R. 1999;40795:42p. 
Genter A, Guillou-Frottier L, Feybesse JL, Nicol N, Dezayes Ch, Schwartz S. Typology of potential hot fractured rock resources in Europe. Geothermics. 2003;32(4-6):701-10. doi:10.1016/S0375-6505(03)00065-8.

Genter A, Cuenot N, Graff JJ, Schmittbuhl J, Villadangos G. La géothermie profonde en France: quelles leçons tirer du projet pilote de Soultz-sous-Forêts pour la réalisation d'un projet industriel à Rittershoffen ? Revue Géologues. 2015;185:97-101.

Gérard A, Kappelmeyer O. The Soultz-sous-Forêts project: proceedings of the first EEC/US workshop on geothermal Hot dry Rocks Technology. 1987. Geothermics Special issue 393-9.

Gérard A, Genter A, Kohl T, Lutz Ph, Rose P, Rummel F. The deep EGS (enhanced geothermal system) project at Soultzsous-Forêts (Alsace, France). Geothermics. 2006a;35(5-6):473-83.

Gérard A, Genter A, Kohl T, Lutz Ph, Rose P, Rummel F. The deep EGS ("enhanced geothermal systems") project at Soultzsous-Forêts (Alsace, France). Geothermics. 2006b;35:473-83.

Haas IO, Hoffmann CR. Temperature gradient in Pechelbronn Oil-Bearing Region, Lower Alsace: its determination and relation to oil reserves. AAPG Bull. 1929;13(10):1257-73.

Herbrich B. Le forage géothermique de Soultz-sous-Forêts (GPK-1), rapport de fin de sondage. 1988. Technical report, 29421, CFG 003.

Hesselbo SP. Spectral gamma-ray logs in relation to clay mineralogy and sequence stratigraphy, Cenozoic of the Atlantic Margin, offshore New Jersey. Proc ODP Sci Results. 1996;150:411-22.

Housse BA. Reconnaissance du potentiel géothermique du Buntsandstein à Strasbourg —Cronenbourg. Géothermie Actualités. 1984;1:36-41.

Howell LG, Frosh A. Gamma-ray well-logging. Geophysics. 1939;4(2):106-14.

Illies JH. Development and tectonic pattern of the Rhinegraben. In: Rothé JP, Sauer K, editors. The Rhinegraben Progress Report. Abh geol Landesamt Baden-Würtemberg 6; 1967. p. 7-9.

Koelbel T, Genter A, Cuenot N, Baumgärtner J, Perret E, Schlagermann P. Soultz-sous-Forêts: Von der Reservoirentwicklung zur Stromerzeugung. Offenburg: GeoTherm Congress; 2011. Accessed 24-25 Feb 2011.

Ménillet F. Notice explicative de la carte géologique de France (1/50000), feuille Haguenau. Zème éd. Carte géologique de France, Service géologique national BRGM; 2015.

Munck F, Walgenwitz F, Maget P, Sauer K, Tietze R. Synthèse géothermique du Fossé Rhénan Supérieur. Commission of the European Communities. BRGM Service Géologique Régional d'Alsace_-Geologishes Landesamt Baden-Württemberg; 1979.

Pribnow D, Schellschmidt R. Thermal tracking of upper crustal fluid flow in the Rhine Graben. Geophys Res Lett. 2000;27(13):1957-60.

Rotstein Y, Schaming M, Rousse S. Tertiary tectonics of the Dannemarie Basin, upper Rhine graben, and regional implications. Int J Earth Sci. 2005;94:669-79. doi:10.1007/s00531-005-0473-4.

Rousse S. Architecture et dynamique des séries marines et continentales de I'Oligocène Moyen et Supérieur du Sud du Fossé rhénan: evolution des milieux de dépôt en contexte de rift en marge de l'avant-pays alpin. Strasbourg: Université de Strasbourg; 2006. p. 483.

Sanjuan B, Millot R, Dezayes C, Brach M. Main characteristics of the deep geothermal brine (5 km) at Soultz-sous-Forêts (France) determined using geochemical and tracer test data. CR Geosci. 2010;342:546-59.

Sausse J, Dezayes C, Dorbath L, Genter A, Place J. 3D model of fracture zones at Soultz-sous-Forêts based on geological data, image logs, induced microseismicity and vertical seismic profiles. CR Geosci. 2010;342(7-8):531-45. doi:10.1016/j.crte.2010.01.011.

Schellschmidt R, Schultz R. Hydrogeothermic studies in the Hot Dry Rock project at Soultz-sous-Forêts. Geotherm Sci Technol. 1991;1:217-38.

Schnaebele R, Haas JO, Hoffmann CR. Monographie géologique du champ pétrolifère de Péchelbronn. Mémoires du Service de la Carte Géologique d'Alsace 7; 1948. p. 254.

Schuler M. Environnements et paléoclimats paléogènes. Palynologie et biostratigraphie de l'Eocène et de l'Oligocène inférieur dans les fossés rhénan, rhodanien et de Hesse. Document BRGM 190. 1990. p. 503.

Schulte T, Zimmermann G, Vuataz FD, Portier S, Tischner T, Junker R, Jatho R, Huenges E. Enhancing geothermal reservoirs. In: geothermal energy systems — exploration, development, and utilization. Weinheim: Wiley-VCH Verlag $\mathrm{GmbH} \&$ Co. KGaA; 2010.

Schumacher ME. Upper Rhine Graben: role of preexisting structure during rift evolution. Tectonics. 2002;21(1):1006. doi:1 0.1029/200ITC900022.

Sissingh W. Comparative tertiary stratigraphy of the Rhine Graben and Molasse Basin: correlation of the Alpine Foreland events. Tectonophysics. 1998;300(1-4):249-84. doi:10.1016/S00040-1951(98)00243-1.

Sissingh W. Tertiary paleogeographic and tectonostratigraphic evolution of the Rhenish Triple Junction. Palaeogeogr Palaeoclimatol Palaeoecol. 2003;196(1-2):229-63. doi:10.1016/50031-0182(03)00320-1.

Sittler C. Le Fossé rhénan en Alsace: aspect structural et histoire géologique. Rev Geogr Phys Geol Dynam. 1969a; 11:465-94.

Sittler C. The sedimentary through of the Rhine Graben. Tectonophysics. 1969b;8(4-6):543-60. doi:10.1016/0040-1951(69)90053-5.

Smolen JJ. Cased hole and production log evaluation. Chapter 14: fluid movement: noise logging. (Tulsa: PennWell Books; 1995. ISBN 13978-0-87814-465-5. p. 365.

Traineau H, Genter A, Cautru JP, Fabriol H, Chèvremont P. Petrography of the granite massif from drill cutting analysis and well log interpretation in the geothermal HDR borehole GPK-1 (Soultz, Alsace, France). European HDR Project at Soultz-sous-Forêts. Geotherm Sci Technol. 1991;3:1-29.

Vernoux JF, Genter A, Razin P, Vinchon C. Geological and petrophysical parameters of a deep fractured sandstone formation as applied to the geothermal applications. EPS-1 borehole, Soultz-sous-Forêts, France. Rapport BRGM/ RR-38622-FR. 1995.

Vidal J, Genter A, Schmittbuhl J. How do permeable fractures in the Triassic sediments of Northen Alsace characterize the top of hydrothermal convective cells? Evidence from Soultz geothermal boreholes (France). Geotherm Energy J. 2015;3:8. doi:10.1186/s40517-015-0026-4. 
Vuataz F-D, Brach M, Criaud A, Fouillac C. Geochemical monitoring of drilling fluids: a powerful tool to forecast and detect formation waters. SPE, Formation Evaluation. 1990. p. 177-184.

Walsh J. Analysis of the relationship between displacements and dimensions of faults. J Struct Geol. 1988;10(3):239-47. doi:10.1016/0191-8141(88)90057-0.

Wannesson J. Rapport régional d'évaluation pétrolière: « Regional Report » Alsace. Rapport interne de l'Institut Français du Pétrole; 1998. p. 75.

Ziegler PA, Dèzes P. Evolution of the lithosphere in the area of the Rhine Rift System. Int J Earth Sci. 2005;94:594-614. doi:10.1007/s00531-005-0474-3.

Submit your manuscript to a SpringerOpen ${ }^{\circ}$ journal and benefit from:

- Convenient online submission

- Rigorous peer review

- Immediate publication on acceptance

- Open access: articles freely available online

- High visibility within the field

- Retaining the copyright to your article

Submit your next manuscript at $\boldsymbol{\nabla}$ springeropen.com 